\title{
UJI KELAYAKAN MESIN FRAIS TYPE SCHAUBLIN 13 MENGGUNAKAN METODA PENGUJIAN KETELITIAN GEOMETRIK
}

\author{
Siska Angraini Rikosa ${ }^{1^{*}}$, Ruzita Sumiati $^{2^{*}}$, Yuli Yetri ${ }^{3^{*}}$ \\ ${ }^{123}$ Jurusan Teknik Mesin, Politeknik Negeri Padang \\ "Email: yuliyetriyetri@gmail.com
}

\begin{abstract}
Abstrak
Mesin Frais termasuk mesin perkakas yang mampu melakukan banyak variasi bentuk pekerjaan. Di bengkel Politeknik Negeri Padang mesin tersebut sudah berumeu 30 tahun dan digunakan untuk keperluan praktek mahasiswa dan proses produksi. Benda kerja dari hasil praktek milling mahasiswa kualitasnya kurang baik yaitu adanya penyimpangan dari karakteristik geometri (ukuran, bentuk dan kehalusan). Keakuratan kinerja mesin perkakas sangat penting dalam proses manufaktur untuk menghasilkan produk yang berkualitas tinggi. Tujuan pengujian adalah untuk mengetahui besarnya penyimpangan geometrik yang terjadi pada keadaan statik di mesin perkakas Frais Type Schaublin 13. Pengujian dilakukan dengan membandingkan nilai penyimpangan hasil pengujian yang telah diambil dengan nilai penyimpangan izin menurut standar ISO 1710. Penyimpangan terjadi pada pengukuran kelurusan dan pengukuran kesejajaran. Pada pengukuran kelurusan diperoleh rata-rata penyimpangan ketelitian geometris $0,0267 \mathrm{~mm}$ dan $0,0228 \mathrm{~mm}$ sedangkan penyimpangan maksimum yang diizinkan adalah $0,02 \mathrm{~mm}$ dengan jarak $300 \mathrm{~mm}$. Pada pengukuran kesejajaran rata-rata penyimpangan ketelitian geometris mesin $0,0741 \mathrm{~mm}$ dan $0,0783 \mathrm{~mm}$ dan penyimpangan maksimum yang diizinkan $0,025 \mathrm{~mm}$ dengan jarak $300 \mathrm{~mm}$. Pengukuran kesejajaran ketelitian geometris mesin melebihi batas penyimpangan maksimum yang diizinkan. Berdasarkan hasil pengukuran kelurusan dan kesejajaran didapatkan penyimpangan yang melebihi batas yang diizinkan pada mesin yang digunakan. Mesin tersebut seharusnya tidak dipakai untuk pekerjaan-pekerjaan yang memiliki kepresisian yang tinggi, dan sebaiknya diganti dengan mesin yang baru.
\end{abstract}

Kata kunci: Mesin Frais, Kelurusan, Kesejajaran, Penyimpangan, Keakuratan

\begin{abstract}
Milling machine categorized as machine tool that is able to do many variations in the form of work. In workshop of the State Polytechnic of Padang, the machine has been operating for 30 years and using for the purposes of student practice and production processes. The workpieces results of student milling practice were poor quality with the existence of deviations from geometric characteristics (size, shape and smoothness). The accuracy of machine tool performance is very important in the manufacturing process to produce high quality products. The aim of the testing is to determine the magnitude of geometric deviations that occur in static conditions on the Schaublin Type Frais machine tool 13. Tests were carried out by comparing the value of deviation test results that were taken with the value of permit deviations according to ISO 1710 standard. On the line measurement, the geometric accuracy deviations were $0.0267 \mathrm{~mm}$ and $0.0228 \mathrm{~mm}$, however, the maximum deviation allowed is $0.02 \mathrm{~mm}$ with a distance of $300 \mathrm{~mm}$. On the measurement of the alignment the average accuracy of the geometric accuracy of the engine were $0.0741 \mathrm{~mm}$ and $0.0783 \mathrm{~mm}$ and the maximum deviation allowed is $0.025 \mathrm{~mm}$ with a distance of $300 \mathrm{~mm}$. Measurement of the geometric accuracy of the machine exceeded the permitted maximum deviation limit. Moreover, based on the results of measurement of line and alignment, the deviations exceeded the permitted limits on the engine used were found. The machine should not be used for jobs that have high precision, and should be replaced with a new engine.
\end{abstract}

Keywords: Machine Milling, Straightness, Alignment, Deviation, Accuracy

\section{Pendahuluan}

Mesin Frais (milling machine) adalah mesin perkakas yang dalam proses pemotongannya dengan menyayat/memakan benda kerja menggunakan alat potong bermata banyak yang berputar (multipoint cutter) yang biasa dikenal dengan pisau frais (milling cutter). Pada saat alat potong (cutter) berputar, gigi-gigi potongnya menyentuh permukaan benda kerja yang dijepit ragum pada meja mesin frais, sehingga terjadilah pemotongan/penyayatan dengan kedalaman sesuai penyetingan. Maka setelah beberapa proses penyayatan jadilah benda produksi sesuai dengan gambar kerja yang dikehendaki. Penyayatan pada benda kerja dengan mesin frais dapat dilakukan pada bidang datar, sisi tegak, miring bahkan pembuatan alur dan roda gigi (Adi Bawanto, 2013). Untuk lebih jelasnya pada Gambar 1 dapat dilihat bagianbagian utama mesin frais

Mesin Frais termasuk mesin perkakas yang mampu melakukan banyak variasi bentuk pekerjaan dibandingkan dengan mesin perkakas lainnya. Permukaan yang datar atau berlekuk, celah, roda gigi, lubang, dove tail, dan lain - lain dengan berbagai bentuk alat potong. Jika mesin digunakan dalam jangka waktu tertentu dapat menyebabkan terjadinya keausan pada elemen 
mesin tersebut sehingga menyebabkan terjadinya penyimpangan terhadap ketelitian standar yang telah ditetapkan.

Keakuratan kinerja mesin perkakas sangat penting dalam proses manufaktur sehingga dapat menghasilkan produk yang berkualitas tinggi. Untuk dapat menghasilkan produk dengan kualitas tinggi tersebut sangat perlu dipertimbangkan kondisi mesin yang digunakan saat proses produksi berlangsung. Penyimpangan ketelitian geometrik suatu mesin dapat diketahui melalui pengujian yang mengacu pada standar yang baku. Pengembangan prosedur pengujian ini sebenarnya telah dirintis oleh G. Schlesinger dalam usahanya membuat standar kelayakan untuk mesin perkakas. (Julian Alfijar, 2005) Mesin Frais yang ada di bengkel Politeknik Negeri Padang yang digunakan untuk keperluan praktek mahasiswa dan kadang digunakan untuk produk sudah berumur 30 tahun. Benda kerja dari hasil praktek milling mahasiswa kualitasnya kurang baik yaitu adanya penyimpangan dari karakteristik geometri (ukuran, bentuk dan kehalusan). Berdasarkan permasalahan tersebut, maka sangat perlu adanya pengujian/pengukuran geometrik pada mesin tersebut. Pengujian dilakukan dengan membandingkan nilai penyimpangan hasil pengujian yang telah diambil dengan nilai penyimpangan izin menurut standar ISO 1710.

Tujuan dilakukan pengujian ini adalah untuk mengetahui besarnya penyimpangan geometrik yang terjadi pada keadaan statik pada mesin perkakas Frais Type Schaublin 13 yang ada di bengkel Jurusan Teknik Mesin Politeknik Negeri Padang. Sehingga diketahui apakah mesin tersebut perlu dilakukan kalibrasi ulang atau proses maintenance terhadap mesin.

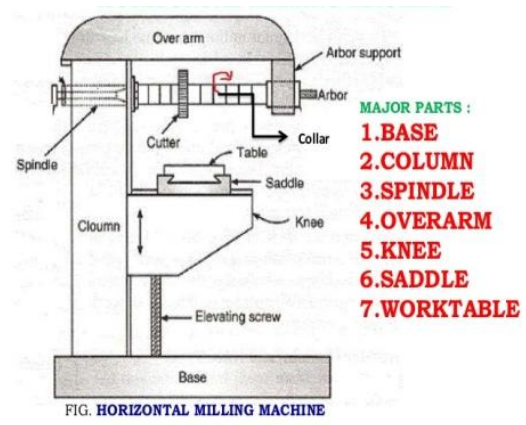

Gambar 1. Bagian Utama Mesin Frais Sumber :

https://image.slidesharecdn.com/millingmachine150325050403-conversion-gate01/95/

\section{Metode Penelitian}

Metode penelitian yang digunakan yaitu metode praktis yaitu melakukan pengukuran langsung pada objek yaitu mesin. Penelitian dilakukan di Bengkel Teknik Mesin Politeknik Negeri Padang. Peralatan yang digunakan dalam pengambilan data adalah:

1) Mesin Frais (milling)

2) Dial indikator

3) Spirit Level (Waterpas)

4) Jangka Sorong (Vernier Calliper)

5) Mistar

6) Spidol / KapurTulis

\section{Alat-Alat Ukur Yang Dipakai Untuk Pengetesan Mesin Perkakas}

Dalam pengetesan mesin perkakas ada beberapa alat-alat ukur yang dipakai dan alatalat tersebut harus mempunyai ketelitian yang tinggi, antara lain:

1) Jam Ukur (Dial Indicator)

Alat ukur ini dipakai untuk mendeteksi perubahan satuan panjang dalam satu arah. Pada alat ini skala yang ada pada penunjuk harus jelas dan mudah dibaca. Untuk pekerjaan biasa dan normal suatu divisi menunjukkan perbedaan 0,01 mm, kalau diperlukan dapat dipakai jam ukur yang lebih teliti yaitu dengan divisi sampai dengan $1 \mu \mathrm{m}$ (satu mikrometer) seperti yang dapat dilihat pada Gambar 2.

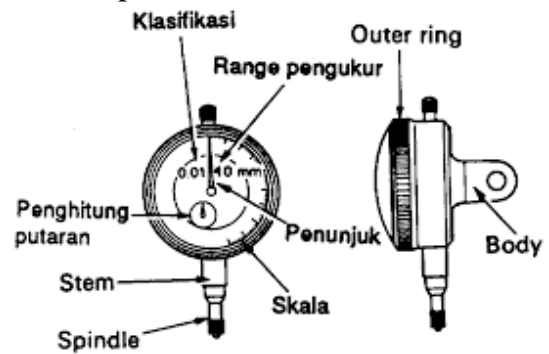

Gambar 2. Jam ukur dan bagian-bagiannya Sumber :

http://classymechanicalengineering.blogspot.com/2 017/11/dial-gauge.html

\section{2) Mandrel Penguji}

Adalah suatu alat yang mewakilkan suatu sumbu yang akan diuji posisinya terhadap elemen-elemen mesin yang lain maupun gerakan sumbu itu terhadap posisinya sendiri.

Ada dua jenis mandrel yang dapat dipakai pada pengujian mesin perkakas, yaitu:

a. Mandrel silindrik, kedua ujungnya mempunyai diameter sama, dan pemakainnya ditumpu oleh dua senter.

b. Mandrel silindrik dengan satu ujung berbentuk tirus, pemakainnya bisa ditumpu oleh kedua ujung senter dan bisa juga 
dipasang pada lubang tirus (sleave) yang ada pada mesin perkakas seperti yang dapat dilihat pada Gambar 3.

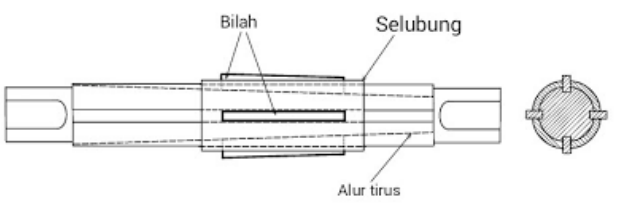

Gambar 3. Mandrel silindrik

Sumber : http://pusat-

lingkaran.blogspot.com/2017/03/memegang-

benda-kerja-dengan-mandrel.html

Mandrel ini terbuat dari bahan baja yang dikeraskan, yang bagian luarnya dilapisi dengan Chrom agar tahan korosi. Ukuran panjangnya bervariasi yaitu, Dalam pemakaiannya biasa dibantu dengan alat ukur lain seperti jam ukur dan blok ukur sebagai penumpu. Jika alat ini ditumpu di kedua ujungnya, maka defleksi yang diijinkan tidak boleh melebihi dari $1 \mu \mathrm{m} / \mathrm{m}$ $(0,00012 \% / \mathrm{ft})$. Ketentuan lain yang harus dipenuhi adalah: $75 \mathrm{~mm}, 150 \mathrm{~mm}, 200 \mathrm{~mm}, 300$ $\mathrm{mm}$, dan $500 \mathrm{~mm}$. Karena fungsinya sebagai wakil sumbu, maka ketelitian yang harus dipunyai baik diameter maupun ukuran panjangnya tidak boleh menyimpang melebihi 2 sampai 3 mikron.

\section{3) Pendatar (Spirit level)}

Pendatar adalah suatu alat yang terdiri dari suatu tabung melengkung berisi cairan gelembung satu, dan tabung itu biasa dipasang pada suatu dasar besi cor. Fungsi utama dari alat ini dapat merasakan perubahan kemiringan suatu bidang, dan perubahan kemiringan itu dapat dihubungkan dengan perubahan ketinggian. Perubahan kemiringan pada alat ini dinyatakan dalam perubahan ketinggian (dalam mikronmeter atau mikron inchi) pada suatu panjang tertentu (dalam meter atau ft).

\section{4) Pelurus (Straight edge)}

Pelurus adalah suatu alat yang berbentuk atau berpenampang segi empat panjang atau I. Alat ukur ini berfungsi untuk mengukur kedataran atau kelurusan bidang atau permukaan komponen mesin perkakas, syarat yang harus dipenuhi oleh peluru ini adalah tidak mudah berubah bentuk (melengkung atau memuai).

5) Siku atau Master Siku (squares or master squares)

Alat ini dipakai untuk mengukur ketegak lurusan atau kesikuan antar dua bidang yang berpasangan atau yang berpotongan yang membentuk sudut 90o. siku atau master siku ini dapat berbentuk siku atau silinder atau bentuk segi.

- Kedatarannya (jika ditumpu kedua ujungnya) tidak boleh melebihi $(2+10 \mathrm{~L})$ mikron atau $(0,0001+10-5 \mathrm{~L})$ inchi

- Kelurusan jika ditumpu kedua ujungnya tidak boleh melebihi $10(2+10$ L) mikron atau $10(0,0001+10-5 \mathrm{~L})$ inchi.

- Kesejajaran jika ditumpu di kedua ujungnya tidak boleh melebihi $15(2+10 \mathrm{~L})$ mikron atau $15(0,0001+10-5 \mathrm{~L})$ inchi.

- Kedataran atau kelurusan yang harus dipunyai adalah, $(2+10 \mathrm{~L})$ mikron atau $(0,0001+10-5 \mathrm{~L})$ inchi, dimana $\mathrm{L}=$ panjang daerah atau sisi kerja siku, sedang untuk kesikuannya 5 mikron/300 mm panjang atau 0,0002 inchi/foot.

Langkah-langkah pengujian:

- Pengukuran Kerataan

1. Persiapkan peralatan yang digunakan seperti spirit level (waterpass).

2. Tentukan mesin frais vertikal serta bidang-bidang yang akan diukur.

3. Letakkan spirit level (waterpass) di atas meja kerja dalam arah memanjang dan melintang seperti yang diperlihatkan pada Gambar 4.

4. Lakukan pengukuran sesuai standar yang digunakan (toleransi yang diizinkan $0,05 \mathrm{~mm}$ dan toleransi lokal $0,02 \mathrm{~mm}$ untuk jarak pengukuran 300 $\mathrm{mm})$.

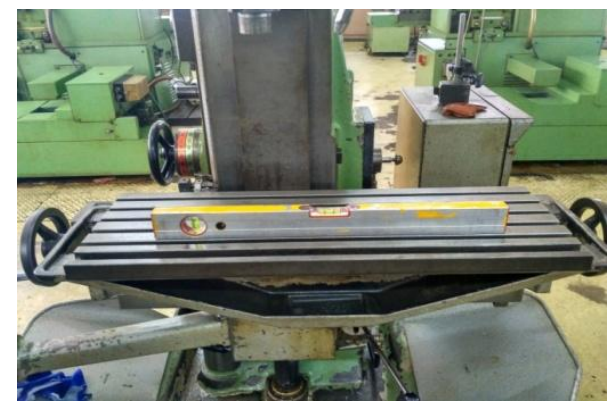

Gambar 4. Pengukuran Kerataan

- Pengukuran Kelurusan

1. Persiapkan peralatan yang digunakan.

2. Tentukan mesin frais vertikal serta bidang-bidang yang akan diukur.

3. Pasangkan jam ukur (dial indikator) dengan dudukannya pada bidang kaku seperti yang diperlihatkan pada Gambar 5.

4. Lakukan pengukuran sesuai yang digunakan (toleransi yang diizinkan 0 0,02 per $100 \mathrm{~mm}$ dan lebih dari 500 mm toleransi $0,01 \mathrm{~mm}$ ). 


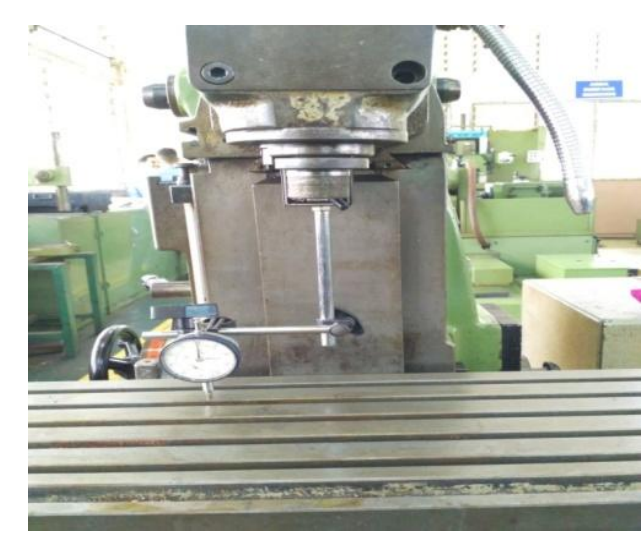

Gambar 5. Pengukuran Kelurusan

- Pengukuran Kesejajaran

1. Persiapkan peralatan yang digunakan.

2. Tentukan mesin frais vertikal serta bidang-bidang yang akan diukur.

3. Pasangkan jam ukur (dial indikator) dengan dudukannya pada bidang kaku seperti pada Gambar 6.

4. Lakukan pengukuran sesuai yang digunakan (toleransi yang diizinkan adalah 0,025 mm dengan jarak 300 $\mathrm{mm})$

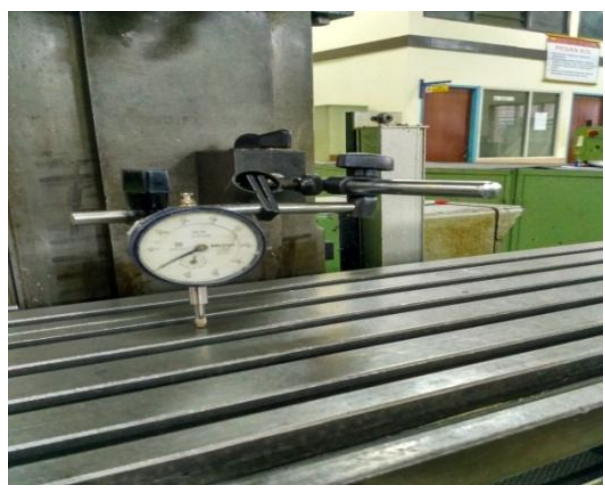

Gambar 6. Pengukuran Kesejajaran

- Pengukuran Ketegaklurusan

1. Bersihkan permukan meja kerja.

2. Letakkan dial indikator pada spindel nose mesin frais vertikal.

3. Sentuhkan ujung stillus jam ukur pada kolom pembimbing seperti yang diperlihatkan pada Gambar 7 di bawah ini.

4. Lakukan Pengukuran sesuai standar yang digunakan (toleransi yang diizinkan adalah $0,02 \mathrm{~mm}$ per 300 $\mathrm{mm}$ dan arah penyimpangan a lebih besar dari $90^{\circ}$.

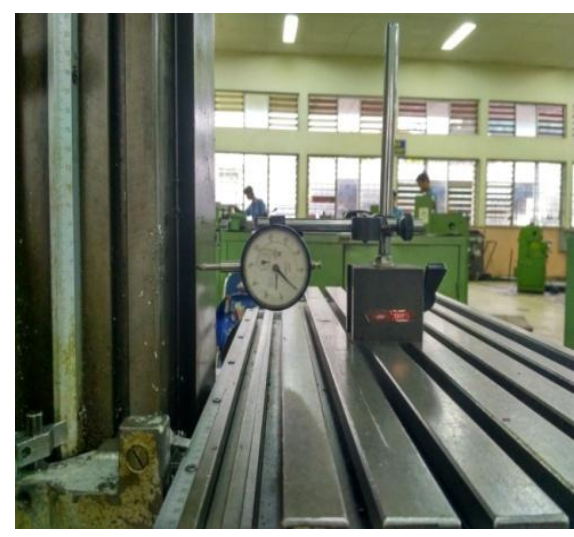

Gambar 7. Pengukuran Ketegaklurusan

- Pengukuran Rotasi

1. Persiapkan peralatan yang digunakan.

2. Tentukan mesin frais vertikal serta bidang-bidang yang akan diukur.

3. Bersihkan spindel nose dan penyenter.

4. Pasangkan jam ukur (dial indikator) dengan dudukannya pada bidang kaku.

5. Tempelkan stillus pada ujung spindle nose seperti yang diperlihatkan pada Gambar 8.

6. Lakukan pengukuran sesuai standar. Toleransi yang diizinkan untuk masing-masing pengukuran adalah sebagai berikut:

a). Simpang putar penyenter toleransi maksimum $0,01 \mathrm{~mm}$.

b). Slip aksial spindel nose toleransi maksimumnya $0,01 \mathrm{~mm}$ untuk diameter 50 $\mathrm{mm}$ dan untuk diameter lebih besar dari 50 mm adalah 0,02 .



Gambar 8. Pengukuran Rotasi

\section{Hasil dan Pembahasan}

Model dari mesin frais type Schaublin 13 dapat dilihat pada Gambar 9 


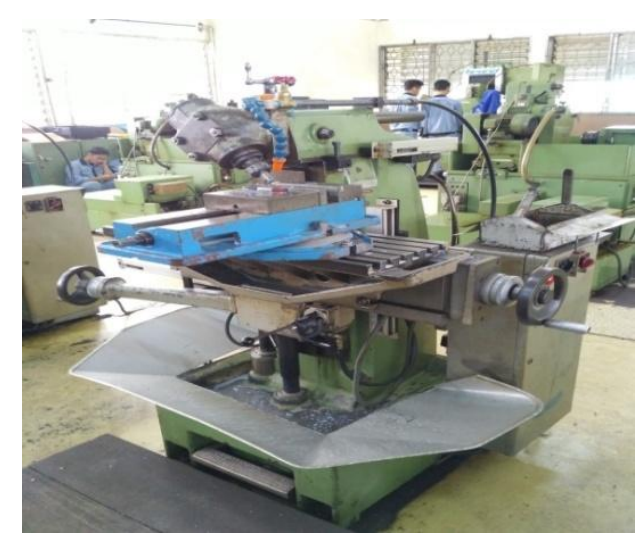

Gambar 9. Mesin Frais Schaublin 13

Spesifikasi dari mesin frais type Schaublin 13 adalah sebagai berikut:

- Merk mesin: SCHAUBLIN SA BEVILARD SUISSE

- Type : 13BL: 318803

- V : 380

- Made in: Switzerland

- $\quad$ Strokes X, Y, Z: 300 x 150 x 375 (mm)

- $\quad$ Spindle speed : 64 - 2000 (rpm)

- Spindle nose : SA 30

- Feeds speed : $12-400(\mathrm{~mm} / \mathrm{min})$

- Weight : Approx. $700(\mathrm{~kg})$

\section{Hasil Pengujian}

\section{1). Pengukuran Kerataan}

Penyelarasan meja kerja dibagi menjadi dua, yaitu:

a. Pengukuran Kerataan Dalam Arah Memanjang. Pengukuran Kerataan dalam arah longitudinal menunjukkan pembacaan pada bagian kiri spirit level pada angka garis ke 3 sedangkan pada bagian kanan spirit level menunjukkan angka nol karena zat cair yang berada pada spirit level berada tepat di tengah-tengah. Spirit level yang digunakan untuk pengujian ini mempunyai ketelitian penyimpangan sebesar $0,02 \mathrm{~mm} / 1000 \mathrm{~mm}$ per divisi. Jadi penyimpangan yang terjadi pada proses penyelarasan meja kerja mesin ini adalah rata-rata 1,5 divisi yang artinya untuk pengukuran sejauh $1000 \mathrm{~mm}$ meja ini mempunyai penyimpangan $0,03 \mathrm{~mm}$ (slop kemiringan garis)

b. Pengukuran Kerataan Dalam Arah Melintang. Penyelarasan dalam arah melintang menunjukkan pembacaan pada bagian kiri spirit level yang sudah diambil tiga kali pengukuran. Pada pengukuran pertama pada meja kerja sebelah kiri arah gelembung sedikit ke kiri yang menandakan bahwa meja kerja bagian sebelah kiri tidak datar, sedangkan pada meja kerja bagian tengah dan kanan arah gelembung berada di tengah-tengah menandakan bahwa meja kerja tersebut datar Batas penyimpangan/toleransi yang diizinkan untuk pengukuran kerataan meja kerja dalam arah melintang adalah $0,04 \mathrm{~mm}$ per $1000 \mathrm{~mm}$. Jadi meja kerja masih dalam batas yang diizinkan

\section{2) Pengukuran Kelurusan}

Pengukuran kelurusan gerak vertikal lutut yang diijinkan adalah 0,025 $\mathrm{mm}$ untuk pengujian sejauh lintasan $300 \mathrm{~mm}$. Data hasil pengujiannya adalah sebagai berikut:

Tanda minus pada tabel menunjukkan bahwa pada saat dilakukan pengujian daerah yang bersangkutan lebih jauh ke alat ukur (dial gauge) dibandingkan titik awal (titik nol) dan begitu juga sebaliknya.

Pada saat dial gauge pada posisi a yang dianggap sebagai titik awal pengukuran posisi jarum diset pada titik nol, setelah dial gauge dipakai untuk mengukur bagian b maka dial gauge akan menunjukkan angka negatif hal ini menunjukkan bahwa permukaan benda kerja yang diukur semakin menjauhi dial gauge, begitu juga sebaliknya. Untuk lebih jelas hasil pengukuran kelurusan I dapat dilihat pada Gambar 10, dan 11. Sedangkan hasil pengukuran ketegaklurusan I disajikan pada Gambar 12, 13 dan 14. Sedangkan hasil pengukuran kesejajaran II dan ketegaklurusan II dapat dilihat pada Gambar 15, 16, dan 17.

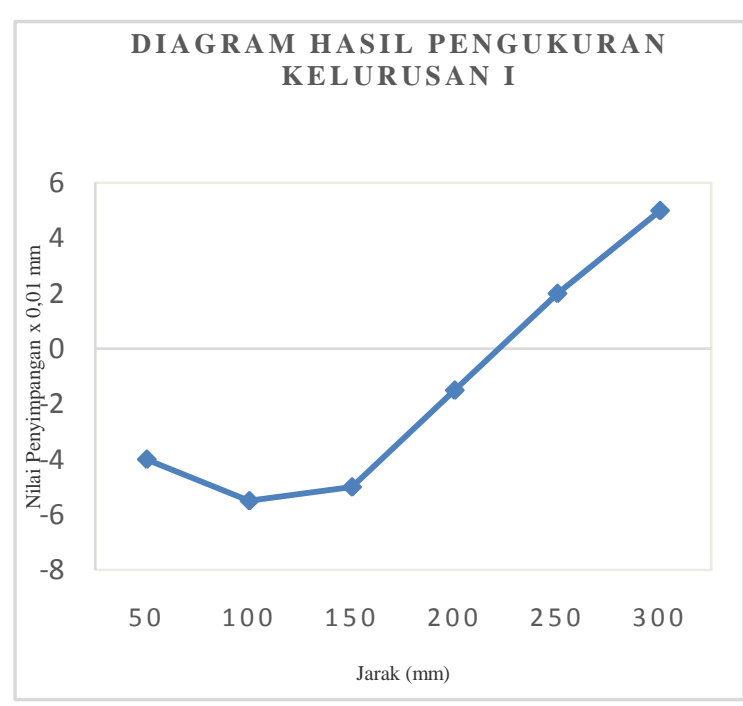

Gambar 10. Diagram Hasil Pengukuran Kelurusan I

Dari Gambar 10 dapat dilihat bahwa penyimpangan yang terjadi untuk pengujian kelurusan gerak lutut dalam arah tegak lurus 
vertikal simetri dengan mesin adalah sebesar $0,03 \mathrm{~mm}$ untuk pengujian sejauh $300 \mathrm{~mm}$ sedangkan penyimpangan maksimum yang dizinkan menurut ISO adalah $0,025 \mathrm{~mm}$. Jadi penyimpangan yang terjadi sudah melebihi batas yang diizinkan.

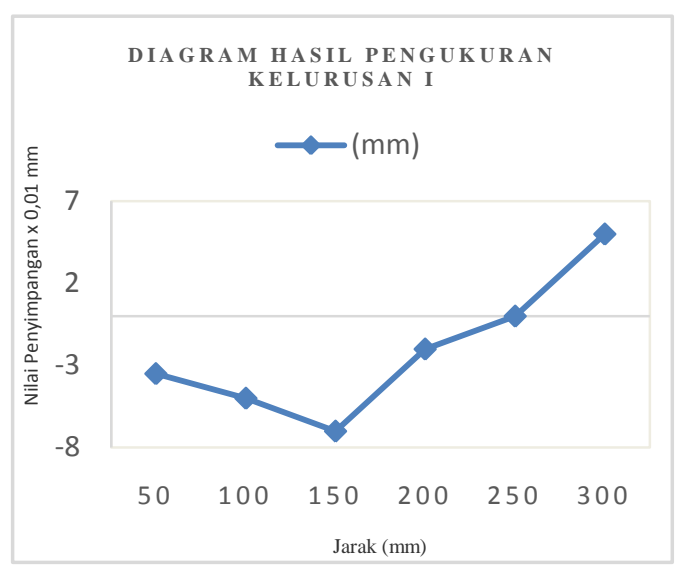

Gambar 11. Diagram Hasil Pengukuran Kelurusan I

Pengukuran kelurusan gerak vertikal lutut baik dalam arah vertikal simetri dengan mesin dan dalam arah bidang tegak lurus terhadap bidang vetikal simetri mesin menunjukkan penyimpangan yang sudah melebihi batas yang diizinkan, hal ini kemungkinan disebabkan oleh:

- Jarak yang terlalu jauh antara bidang referensi pada mesin dengan bidang luncur pada meja.

- Keausan pada bidang luncur baik bidang luncur referensi pada mesin maupun meja kerja sehingga menjadi tidak rata dan menyebabkan ketidaksamaan gerak kerja.

\section{3) Pengukuran Ketegaklurusan}

a. Pengukuran ketegaklurusan meja kerja terhadap kolom pembimbing

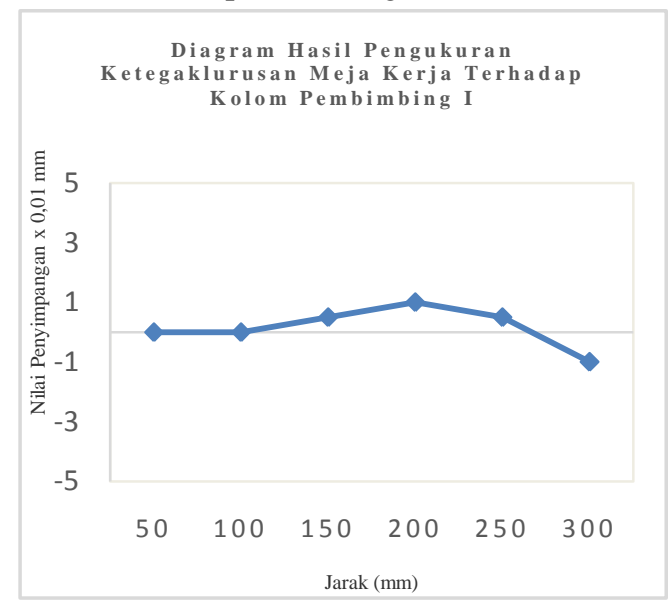

Gambar 12. Diagram Hasil Pengukuran Ketegaklurusan I

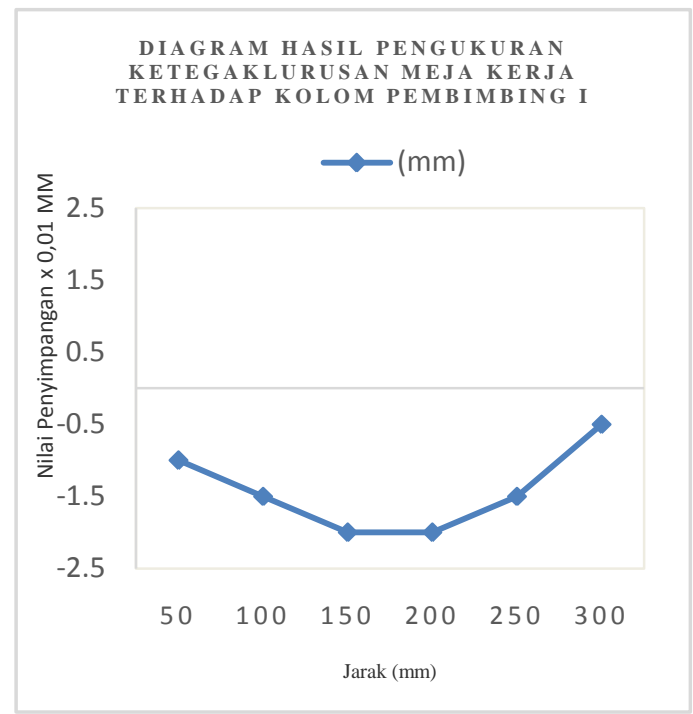

Gambar 13. Diagram Hasil Pengukuran Ketegaklurusan II

Dari data hasil pengujian maka dapat diketahui bahwa besarnya penyimpangan yang terjadi $0,012 \mathrm{~mm}$ untuk pengujian sepanjang $300 \mathrm{~mm}$ sedangkan penyimpangan yang diizinkan adalah $0,025 \mathrm{~mm}$ per $300 \mathrm{~mm}$. Jadi penyimpangan yang terjadi masih dalam batas yang diizinkan oleh ISO

b. Pengukuran ketegaklurusan meja kerja terhadap gerak vertikal sumbu utama.

Penyimpangan maksimum yang diizinkan untuk pengujian ini adalah $0,025 \mathrm{~mm}$ untuk pengujian sepanjang lintasan $300 \mathrm{~mm}$.

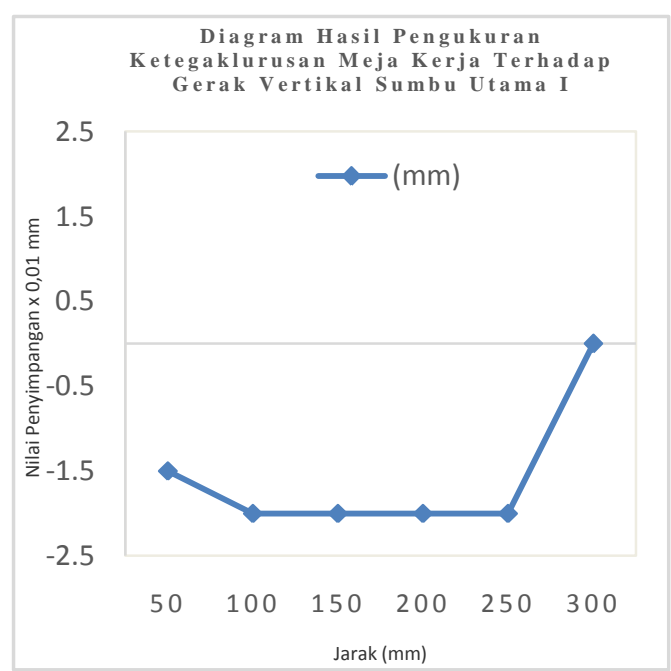

Gambar 14. Diagram Hasil Pengukuran Ketegaklurusan I 


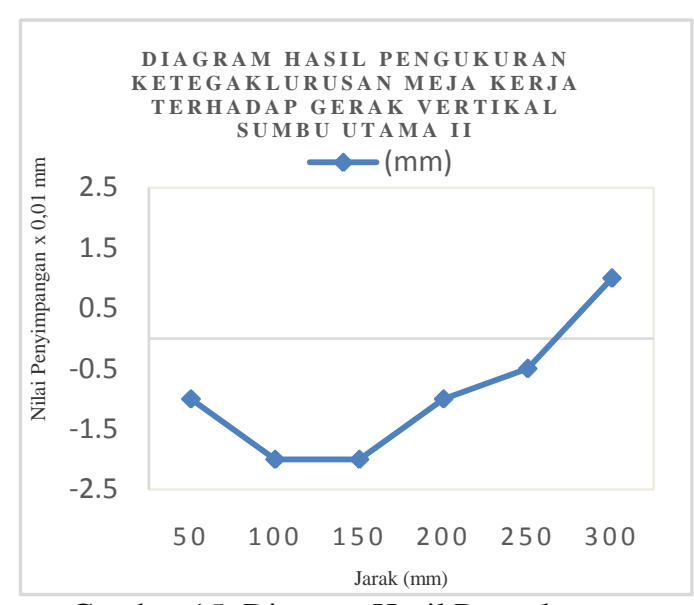

Gambar 15. Diagram Hasil Pengukuran Ketegaklurusan II

\section{4) Pengukuran Kesejajaran}

Pada pengukuran kesejajaran didapatkan nilai penyimpangan seperti yang diperlihatkan grafik pada Gambar 16.

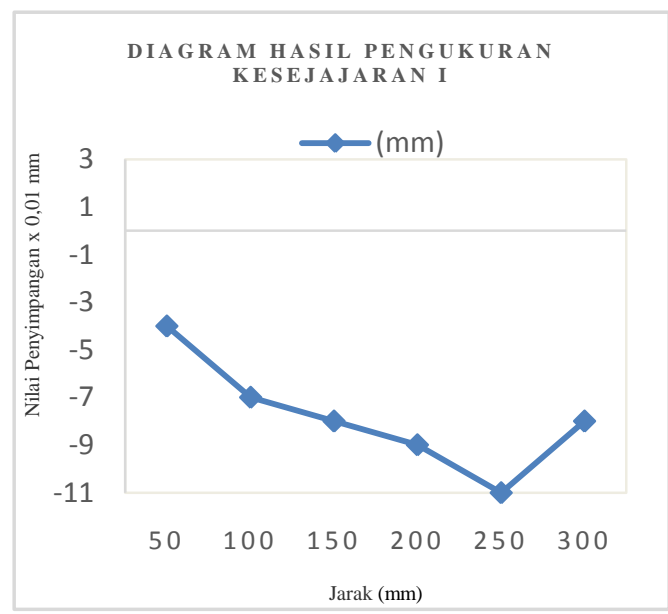

Gambar 16. Diagram Hasil Pengukuran Kesejajaran I



Gambar 17. Diagram Hasil Pengukuran Kesejajaran II

\section{5) Pengukuran Rotasi}

Penyimpangan maksimum yang diizinkan untuk pengujian ini adalah:

- Untuk pengujian simpang putar penyenter (run out) penyimpangan maksimum yang diizinkan adalah $0,01 \mathrm{~mm}$.

- Untuk pengujian slip aksial spindle nose penyimpangan maksimum yang diizinkan adalah $0,01 \mathrm{~mm}$ untuk diameter $50 \mathrm{~mm}$ dan untuk diameter lebih besar dari $50 \mathrm{~mm}$ adalah 0,02 $\mathrm{mm}$.

Pada pengukuran rotasi didapatkan nilai penyimpangan seperti yang diperlihatkan pada grafik Gambar 18 dan 19.

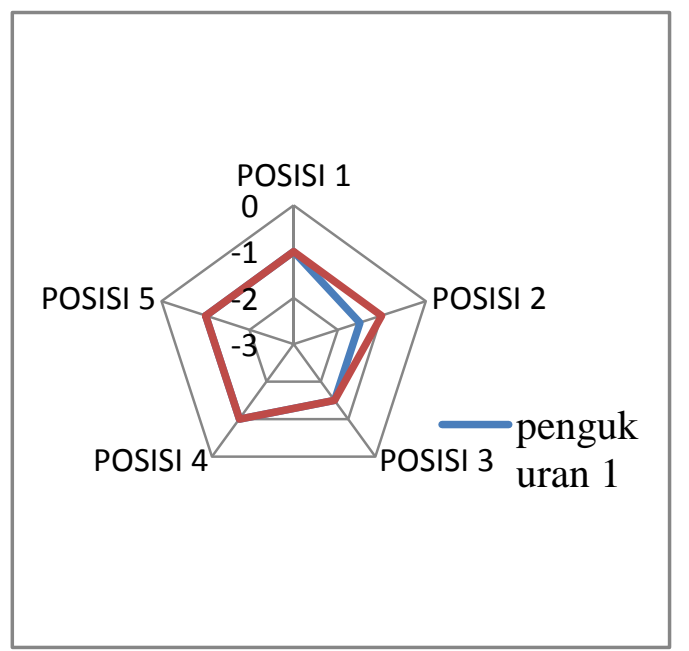

Gambar 18. Diagram Hasil Pengukuran Rotasi (Simpang Putar)

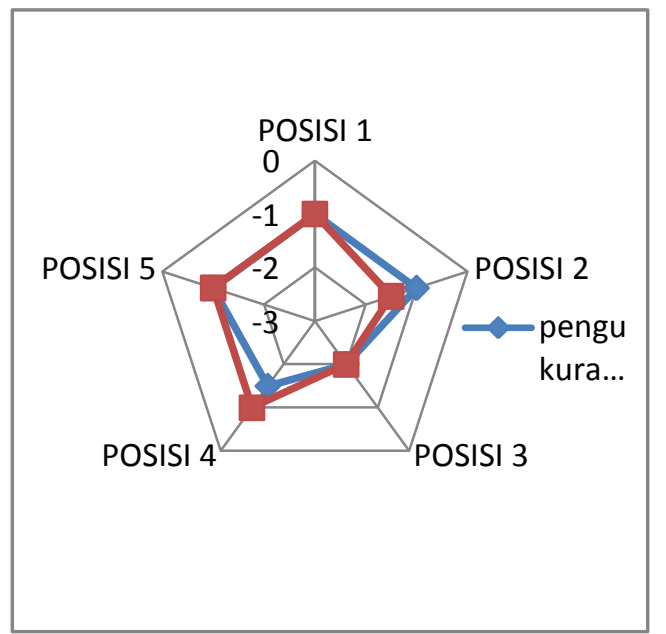

Gambar 19. Diagram hasil pengukuran Rotasi (Slip Aksial)

\section{Analisa Hasil Pengujian}

Menurut hasil pengujian yang dilakukan dapat dianalisa bahwa setelah dilakukan pengujian didapatkan hasil yaitu, mesin frais type schaublin 13 sudah tidak layak digunakan 
karena banyak mengalami penyimpangan yang melebehi penyimpangan maksimum yang sudah ditentukan.Penyimpangan terjadi pada pengukuran kelurusan dan pengukuran kesajajaran. Pada pengukuran kelurusan didapatkan hasil rata-rata penyimpangan ketelitian geometris adalah $0,0267 \mathrm{~mm}$ dan $0,0228 \mathrm{~mm}$ sedangkan penyimpangan maksimum yang diizinkan adalah $0,02 \mathrm{~mm}$ dengan jarak $300 \mathrm{~mm}$. Jadi, pengukuran kelurusan ketelitian geometris mesin frais melebihi batas penyimpangan maksimum yang diizinkan. Sedangkan pada pengukuran kesejajaran didapatkan hasil rata-rata penyimpangan ketelitian geometris mesin adalah $0,0741 \mathrm{~mm}$ dan $0,0783 \mathrm{~mm}$ dan penyimpangan maksimum yang diizinkan adalah 0,025 mm dengan jarak $300 \mathrm{~mm}$. Jadi pengukuran kesejajaran ketelitian geometris mesin juga melebihi batas penyimpangan maksimum yang diizinkan.

Pengukuran kelurusan dan pengukuran kesejajaran menunjukkan penyimpangan yang sudah melebihi batas yang diizinkan, hal ini kemungkinan disebabkan oleh:

- Jarak yang terlalu jauh antara bidang referensi pada mesin dengan bidang luncur pada meja.

- Keausan pasak luncur.

- Keausan pada bidang luncur baik bidang luncur referensi pada mesin maupun meja kerja sehingga menjadi tidak rata dan menyebabkan ketidaksamaan gerak kerja.

- Adanya kesalahan dalam proses pengukuran.

\section{Kesimpulan}

Adapun kesimpulan yang dapat penulis berikan diantaranya adalah sebagai berikut:

1) Pengujian Uji Kelayakan Mesin Frais Type Schaublin 13 dengan menggunakan metoda ketelitian geometrik ini dilakukan dengan melakukan beberapa macam pengukuran, diantaranya sebagai berikut:
a. Pengukuran Kerataan
b. Pengukuran Kelurusan
c. Pengukuran Ketegaklurusan
d. Pengukuran Kesejajaran
e. Pengukuran Rotasi

2) Nilai penyimpangan yang diizinkan atau toleransi dalam pengujian ketelitian geometrik menggunakan standar ISO sebagai standar melakukan pengujian.

3) Penyimpangan terjadi pada pengukuran kelurusan dan pengukuran kesajajaran. Pada pengukuran kelurusan didapatkan hasil rata-rata penyimpangan ketelitian geometris adalah $0,0267 \mathrm{~mm}$ dan 0,0228 mm sedangkan penyimpangan maksimum yang diizinkan adalah 0,02 $\mathrm{mm}$ dengan jarak $300 \mathrm{~mm}$. Jadi, pengukuran kelurusan ketelitian geometris mesin frais melebihi batas penyimpangan maksimum yang diizinkan. Sedangkan pada pengukuran kesejajaran didapatkan hasil rata-rata penyimpangan ketelitian geometris mesin adalah $0,0741 \mathrm{~mm}$ dan $0,0783 \mathrm{~mm}$ dan penyimpangan maksimum yang diizinkan adalah 0,025 mm dengan jarak $300 \mathrm{~mm}$. Jadi pengukuran kesejajaran ketelitian geometris mesin juga melebihi batas penyimpangan maksimum yang diizinkan.

4) Berdasarkan hasil pengukuran di atas didapatkan bahwa masih terdapat penyimpangan yang melebihi batas penyimpangan yang diizinkan pada mesin yang digunakan. Mesin tersebut seharusnya tidak dipakai untuk pekerjaan-pekerjaan yang memiliki kepresisian yang tinggi, dan sebaiknya diganti dengan mesin yang baru.

\section{Daftar Pustaka}

Alfijar, Julian dan Purnomo. 2005. Studi Kemampuan dan Keandalan Mesin Frais C2YT melalui Pengujian Karakteristik Statik menurut standar ISO 1710. Traksi. Vol. 3. No. 2 Desember 2005

Apriana, Asep dkk. 2015. Analisa Kelayakan Mesin Milling F3 dengan Pengujian Ketelitian Geometrik. Politeknologi Vol. 14. No. 3 September 2015

Tolosi, Krisnal. 2003. Analisis Ketelitian Geometrik Mesin Frais Horizontal Kunzman UF6N Di Laboratorium Manufaktur Teknik Mesin Unsrat.

ISO 1710-1. Test Condition For Milling Machine With Table Of Variable HeightTesting Of Accuracy-Part 1, Machine With Horizontal Spindle

Daryanto. 2010. Dasar-dasar Teknik Mesin. Jakarta. Rineka Cipta

Bawanto, Adi. 2013. Mesin Untuk Operasi Dasar. Jakarta. Insania 